\title{
A Case of Gitelman Syndrome; Incidentally Diagnosed in Elderly
}

\author{
Tesadüfen Tanı Alan ileri Yaş Bir Gitelman Sendromu Olgusu
}

(iD Selma KARAAHMETOĞLU, io Mehmet Veysel COŞKUN

Ankara City Hospital, Clinic of Internal Medicine, Ankara, Turkey

\section{ABSTRACT}

Gitelman syndrome is an autosomal recessive renal tubular disease that is followed by symptoms, such as fatigue, muscle weakness, tetany, polydipsia, and nocturia. Additionally, hypokalemia, hypomagnesemia, and hypocalciuria are observed and it is usually diagnosed in adulthood but some cases are coincidentally diagnosed in the elderly. Herein, we had a 60-year-old female patient who was incidentally found to have hypokalemia and then diagnosed with Gitelman syndrome by furosemide loading test and SCL12A3 gene mutation detection.

Keywords: Bartter syndrome, Gitelman syndrome, elderly

\section{ÖZ}

Gitelman sendromu halsizlik, kas güçsüzlüğü, tetani, polidipsi ve noktüri gibi semptolarla seyredebilen otozomal resesif kalıtımlı renal tübüler bir hastalıktır. Hipokaleminin yanında hipomagnezemi ve hipokalsiüri ile seyreder ve genellikle erişkin yaşta teşhis edilir. Ancak bazı olgularda tesadüfen ileri yaşlarda da tanı alabilmektedir. Biz de tesadüfen izole hipokalemi tespit edilen sonrasında furosemid yükleme testi yapılarak ve $S C L 12 A 3$ gen mutasyonu saptanarak Gitelman sendromu tanısı konulan 60 yaşında bir kadın hastayı sunmayı amaçladık.

Anahtar Sözcükler: Bartter sendromu, Gitelman sendromu, ileri yaş

\section{Introduction}

Gitelman syndrome is an autosomal recessive inherited familial tubulopathy with hypokalemia, hypomagnesemia, and hypocalciuria that is accompanied by metabolic alkalosis (1). It occurs due to the $S C L 12 A 3$ gene mutation on the $16^{\text {th }}$ chromosome encoding, the thiazide-sensitive sodium-chloride cotransporter that is expressed in the distal convoluted renal tubule (2-4). Unlike Bartter syndrome, which is a familial tubulopathy, Gitelman syndrome is mostly diagnosed in adulthood; however, some rare cases in the elderly are also observed $(5,6)$. Herein, a 60-year-old female patient who was diagnosed with Gitelman syndrome by furosemide diuretic loading test and SCL12A3 gene mutation detection after the incidental detection of hypokalemia in an outpatient clinic control is presented.

\section{Case Report}

A 60-year-old female patient with no past medical history and use of any drugs was admitted to our outpatient clinic with complaints of long-standing weakness, fatigue, and shortness of breath with mild to moderate exertion.

Physical examination revealed normal respiratory sounds and other system findings. No pathology was found in the posteroanterior chest radiography, electrocardiogram, transthoracic echocardiography, and renal ultrasonography. The blood biochemistry revealed a potassium level of $2.65 \mathrm{mmol} / \mathrm{L}$, chloride of $98 \mathrm{mmol} / \mathrm{L}$, the calcium of $9.6 \mathrm{mg} / \mathrm{dL}$, magnesium of $1.2 \mathrm{mg} / \mathrm{dL}$ (normal range: $1.6-2.6 \mathrm{mg} / \mathrm{dL}$ ), whereas sodium, blood urea nitrogen, and serum creatinine were within normal range. The arterial blood gas $\mathrm{pH}$ was 7.49 , partial oxygen pressure was $83 \mathrm{mmHg}$, partial carbon dioxide pressure was $36 \mathrm{mmHg}$,

Address for Correspondence: Mehmet Veysel COŞKUN, Ankara City Hospital, Clinic of Internal Medicine,

E-mail: coskun.veysel@gmail.com ORCID ID: orcid.org/0000-0002-6626-9518

Cite this article as: Karaahmetoğlu S, Coşkun MV. A Case of Gitelman Syndrome; Incidentally Diagnosed in Elderly. Bezmialem Science 2022;10(1):111-3 
bicarbonate $\left(\mathrm{HCO}_{3}\right)$ was $29 \mathrm{mmol} / \mathrm{L}$, and oxygen saturation was 98.3. Complete urinalysis revealed specific gravity of 1.013 and $\mathrm{pH}$ of 7 without proteinuria or glycosuria. The 24-hour urine revealed a calcium level of $18 \mathrm{mg} /$ day (normal range: $100-320 \mathrm{mg} /$ day), whereas sodium, potassium, and chlorine were within the normal range. Further laboratory evaluation revealed the thyroid-stimulating hormone, free T4, and serum basal cortisol within the normal range. After an overnight supine position, plasma renin activity, and aldosterone level was found as $3.4 \mathrm{ng} / \mathrm{mL} / \mathrm{h}$ (normal range: $0.51-2.61$ $\mathrm{ng} / \mathrm{mL} / \mathrm{h}$ ) and $6.04 \mathrm{ng} / \mathrm{dL}$ (normal range: 3-16 ng/dL), respectively (Table 1). The knee radiography did not reveal any abnormal findings.

According to these findings, the patient was believed to have Gitelman syndrome, thus intravenous (IV) replacement treatment started with $7.5 \%$ potassium chloride $(7.5 \% 10 \mathrm{~mL}$ potassium chloride; Onfarma) and 15\% magnesium sulfate (15\% magnesium sulfate; Biofarma). After elevating the serum potassium value to the normal range (potassium: $4.36 \mathrm{mmol} / \mathrm{L}$ ), the diuretic loading test was performed with $40 \mathrm{mg}$ of IV furosemide (Furoson $40 \mathrm{mg} / 4 \mathrm{~mL}$; Onfarma) due to insufficient thiazide preparation in our country after $12 \mathrm{~h}$ of fasting. Serum and spot urine electrolyte levels were measured before and after furosemide infusion in the patient who was closely monitored during the test (Table 2). Increased furosemide response in the urine (increased sodium, potassium, and chloride excretion) was interpreted in favor of Gitelman syndrome. The patient was followedup in our clinic for another day after the test. Serum potassium and magnesium levels of the patient's sister were checked for family screening and were observed within the normal range. For genetic

Table 1. Biochemical profile of the patient

\begin{tabular}{|c|c|c|}
\hline & Patient ranges & Normal ranges \\
\hline \multicolumn{3}{|l|}{ Serum electrolytes } \\
\hline $\mathrm{Na}(\mathrm{mmol} / \mathrm{L})$ & 140 & $135-145$ \\
\hline $\mathrm{K}(\mathrm{mmol} / \mathrm{L})$ & 2.65 & $3.5-5.5$ \\
\hline $\mathrm{Mg}(\mathrm{mmol} / \mathrm{L})$ & 1.2 & $1.6-2.6$ \\
\hline $\mathrm{Ca}(\mathrm{mmol} / \mathrm{L})$ & 9.6 & $8-12$ \\
\hline $\mathrm{Cl}(\mathrm{mmol} / \mathrm{L})$ & 98 & $98-105$ \\
\hline \multicolumn{3}{|l|}{ 24-hour urine electrolytes } \\
\hline $\mathrm{Na}(\mathrm{mmol} /$ day $)$ & 210 & $40-220$ \\
\hline K (mmol/day) & 92 & $25-125$ \\
\hline Ca (mmol/day) & 18 & $100-320$ \\
\hline $\mathrm{Cl}$ (mmol/day) & 218 & $200-300$ \\
\hline \multicolumn{3}{|l|}{ Blood gases } \\
\hline $\mathrm{pH}$ & 7.49 & $7.35-7.45$ \\
\hline $\mathrm{HCO} 3$ (mmol/L) & 29 & $22-24$ \\
\hline $\mathrm{PCO} 2(\mathrm{mmHg})$ & 83 & $35-45$ \\
\hline \multicolumn{3}{|l|}{ Others } \\
\hline Serum basal cortisol ( $\mu \mathrm{g} / \mathrm{dL})$ & 10.98 & $10-12$ \\
\hline $\begin{array}{l}\text { Plasma renin activity* (ng/mL/ } \\
\text { saat) }\end{array}$ & 3.4 & $0.51-2.61$ \\
\hline $\begin{array}{l}\text { Serum aldosterone level* (ng/ } \\
d \mathrm{~d})\end{array}$ & 6.04 & $3-16$ \\
\hline
\end{tabular}

analysis, $2 \mathrm{~mL}$ of venous blood was taken to the EDTA tube and sent to the genetic laboratory. The diagnosis of Gitelman syndrome was confirmed by detecting homozygous mutations of the SLC12A3 gene (c.2869A > T [p.Lys957Ter]) in the chromosomal analysis.

Upon the absence of any complaints during follow-up, the patient was discharged with the control of spironolactone (Aldactone $25 \mathrm{mg}$; Aris), magnesium citrate (Magnesium Diaspora at $610 \mathrm{mg}$ Şase; Assos Pharma), and potassium citrate/potassium $\mathrm{HCO}_{3}$ (Kalinor $8 \mathrm{mg}$; Abbot). In the outpatient follow-up, the complaints of the patient regressed and serum potassium and magnesium levels were within normal range.

\section{Discussion}

Gitelman syndrome is one of the causes of chronic and treatmentresistant hypokalemia (5) and is usually diagnosed in early adulthood with symptoms of muscle weakness, fatigue, and tetany. Normal blood pressure, hypokalemia, hypomagnesemia, metabolic alkalosis, and hypocalciuria are prominent features $(7,8)$. Patients with Gitelman syndrome are mostly clinically and biochemically diagnosed, and no further investigation is needed. However, Bartter syndrome should be considered in the differential diagnosis.

A60-year-old female patient was admitted to our clinic with complaints of weakness, fatigue, and shortness of breath with mild to moderate exertion. She was normotensive with hypokalemic metabolic alkalosis along with hypomagnesemia and hypocalciuria. Chondrocalcinosis was not detected in the patient who had a slight pain in her knees while climbing the stairs. Her clinical and biochemical parameters were consistent with Gitelman syndrome, except for the patient's old age. Even though rare in the literature, some are cases of Gitelman syndrome are diagnosed in old age $(6,9)$.

History, clinical, and biochemical parameters of the patient can be used to differentiate familial tubulopathies; however, some Bartter syndrome variants may exhibit similarities to Gitelman syndrome (5). Genetic analysis is an expensive, long time consuming, and exhausting process; however, it is the most specific method for tubulopathy differentiation (10). In our case, the diagnosis of Gitelman syndrome was confirmed by detecting homozygous mutations of the SLC12A3 gene on the 16th chromosome [c.2869A>T (p.Lys957Ter)] in the chromosomal analysis. The serum electrolyte levels of the patient's sister were checked to demonstrate autosomal recessive inheritance but no pathology was found.

Another method for differential diagnosis is the diuretic loading test (11). However, the patient should not have an electrolyte

Table 2. Furosemide loading test results: fractionated electrolyte clearance (FEx) before/after furosemide and the number of changes ( $\triangle \mathrm{FE}$

\begin{tabular}{|l|l|l|l|}
\hline & $\begin{array}{l}\text { Before } \\
\text { furosemide }\end{array}$ & After furosemide & $\Delta \mathrm{FE}$ \\
\hline FENa (\%) & 0.24 & 16.44 & 16.2 \\
\hline FECl (\%) & 0.35 & 23.31 & 23.35 \\
\hline FEK (\%) & 10.78 & 61.22 & 50.44 \\
\hline
\end{tabular}


imbalance and must be normotensive in this test (12). Only a furosemide diuretic loading test was performed in our case due to insufficient pure thiazide preparation in our country, wherein increased tubule response to furosemide was evaluated in favor of Gitelman syndrome.

The treatment of Gitelman syndrome recommended the patient to take a diet rich in potassium and magnesium and the patient is prescribed oral potassium and magnesium supplements. Potassium-sparing diuretics and prostaglandin analogs are also agents that can be used in the treatment (13).

The patient was discharged with oral potassium citrate/potassium $\mathrm{HCO}_{3}(8 \mathrm{mg} /$ day $)$, magnesium citrate $(610 \mathrm{mg} /$ day $)$, and spironolactone $(25 \mathrm{mg} /$ day), and in outpatient clinic control, her electrolyte levels were detected within the normal range and her complaints also declined.

In conclusion, Gitelman syndrome must be considered in elderly patients although frequently diagnosed in young/adult cases, and a furosemide loading test can be used for Gitelman syndrome diagnosis as an alternative to genetic testing because of its ease in application and is cheap and fast.

\section{Ethics}

\section{Informed Consent:}

Peer-review: Externally peer reviewed.

\section{Authorship Contributions}

Concept: M.V.C., Design: M.V.C., Data Collection or Processing: S.K., Analysis or Interpretation: S.K., Literature Search: M.V.C., Writing: M.V.C.

Conflict of Interest: No conflict of interest was declared by the authors.

Financial Disclosure: The authors declared that this study received no financial support.

\section{References}

1. Gitelman HJ, Graham JB, Welt LG. A new familial disorder characterized by hypokalemia and hypomagnesemia. Trans Assoc Am Physicians 1966;79:221-35.
2. Simon DB, Nelson-Williams C, Bia MJ, Ellison D, Karet FE, Molina AM, et al. Gitelman's variant of Bartter's syndrome, inherited hypokalemic alkalosis: is caused by mutation in the thiazide sensitive $\mathrm{Na}-\mathrm{Cl}$ cotransporter. Nat Genet 1996;12:24-30.

3. Lemmink HH, Knoers NV, Károlyi L, van Dijk H, Niaudet P, Antignac C, Guay-Woodford LM, et al. Novel mutations in the thiazide sensitive $\mathrm{NaCL}$ cotransporter gene in patients with Gitelman syndrome with predominant localization to the $\mathrm{C}$ terminal domain. Kidney Int 1998;54:720-30.

4. Al Shibli A, Hassib N. Bartter and Gitelman syndromes: Spectrum of clinical manifestations caused by different mutations. World J Methodol 2015;5:55.

5. Molin CZD, Trevisol, DJ. Persistent severe hypokalemia: Gitelman syndrome and differential diagnosis. J Bras Nefrol 2017;39:337-40.

6. Rahul R. Gitelman's syndrome-incidentally detected in an elderly female. Int J Res Med Sci 2016;4:1257-9.

7. Peters M, Jeck N, Reinalter S, Leonhardt A, Tönshoff B, Klaus G Gü, et al. Clinical presentation of genetically defined patients with hypokalemic salt losing tubulopathies. Am J Med 2002;112:183-90.

8. Cobeta-garcia JC, Gascon A, Iglesias E, Estopiñán V. Chondrcalcinosis and Gitelman's syndrome. A new association? Ann Rheum Dis 1998;57:748-9.

9. Hashida T, Yamada M, Hashimoto K, Satoh T, Okada S, Shibusawa $\mathrm{N}$, et al. Loss of consciousness and hypokalemia in an elderly man with a mutation of the thiazide-sensitive $\mathrm{Na}-\mathrm{Cl}$ cotransporter gene. Endocr J 2006;53:859-63.

10. Simon DB, Lifton RP. The molecular basis of inherited hypokalemic alkalosis Bartter's and Gitelman's syndrome. Am J Physiol 1996;271:F961-6.

11. Goswami RP, Mandal S, Karmakar PS, Ghosh A. Diuretic loading test and use of Bartter's Normogram in diagnosing a case of Gitelman's syndrome: Relook into pathophysiology. Indian J Nephrol 2011;21:289-92.

12. Colussi G, Bettinelli A, Tedeschi S, De Ferrari ME, Syrén ML, Borsa $\mathrm{N}$, et al. A thiazide test for the diagnosis of renal tubular hypokalemic disorders. Clin J Am Soc Nephrol 2007;2:454-60.

13. Wang F, Shi C, Cui Y, Li C, Tong A. Mutation profile and treatment of Gitelman syndrome in Chinese patients. J Clin and Exp Nephrol 2017;21:293-99. 